\author{
JACEK Z. KUBIAK ${ }^{1,2}$ \\ ${ }^{1}$ Zakład Embriologii Doświadczalnej \\ Instytut Genetyki i Biotechnologii Zwierzat PAN \\ Postępu 36A, Jastrzębiec, 05-552 Magdalenka \\ ${ }^{2}$ UnivRennes, UMR 6290, CNRS \\ Institute of Genetics and Development of Rennes \\ Faculty of Medicine \\ Rennes, France \\ E-mail: j.kubiak@igbzpan.pl \\ jacek.kubiak@univ-rennes1.fr
}

\title{
ROLA MAKROFAGÓW I MONOCYTÓW W INFEKCJI SARS-COV-2 I W CIĘ̇̇KIM PRZEBIEGU COVID-19
}

\section{WSTEP}

Makrofagi i monocyty (ich prekursory krażące $\mathrm{w}$ krwi) wraz $z$ neutrofilami stanowią pierwsza linię obrony organizmu w momencie infekcji wywołanej przez wniknięcia zarazka: wirusa, bakterii, grzyba czy innego patogenu. Sa niezwykle ważnym elementem odporności wrodzonej. Już na początku pandemii COVID-19 okazało się, że makrofagi odgrywaja niezwykle istotna rolę obronna $\mathrm{w}$ momencie infekcji SARS-CoV-2. Jednak to również makrofagi przyczyniaja sie do wystapienia tzw. burzy cytokinowej, która towarzyszy zapaleniu płuc występujaccemu podczas ciężkiego przebiegu COVID-19. Co więcej, moga one również przyczyniać się do licznych powikłań po przejściu tej choroby. Dlatego identyfikacja molekularnych mechanizmów działania makrofagów ma ogromne znaczenie dla poznania i leczenia COVID-19.

\section{PIERWSZE OBSERWACJE DOTYCZĄCE COVID-19}

COVID-19 jest choroba wywołana przez zupełnie nowy, odzwierzęcy zarazek - koronawirus SARS-CoV-2 (LAI i współaut. 2020). Pojawienie się COVID-19 było precedensem w nauce, gdyż pozwoliło na prześledzenie tempa pojawiania się informacji naukowych poczawszy od punktu zerowego, kiedy nic nie było jeszcze wiadomo o samej chorobie i jej przyczynach. Zdobywanie kolejnych informacji dotyczących samego koronawirusa jak i wywoływanej przez niego choroby początkowo szło bardzo opornie. Było o wiele więcej pytań niż rzetelnych odpowiedzi. Większość spekulacji na temat SARS-CoV-2 i COVID-19 pochodziła $z$ badań prowadzonych uprzednio na innych, podobnych koronawirusach, które wcześniej przeszły ze zwierząt na ludzi, np. SARS w 2002 r. i MERS w 2012 r. (DA COSTA i współaut. 2020). Jednak COVID-19, choroba wywoływana przez SARS-CoV-2 u ludzi, wykazywała podobieństwa do SARS i MERS tylko w bardzo małym zakresie. Wspólnym czynnikiem było zapalenie płuc wywoływane przez wszystkie koronawirusy, ale szczegóły przebiegu tych chorób były bardzo różne. Nie było wiadomo dlaczego SARS-CoV-2, w przeciwieństwie do SARS i MERS, wywołuje u pacjentów cała gamę reakcji, które miały w ogromnej większości gwałtowny przebieg. Pytano dlaczego jedni pacjenci przechodza zakażenie SARS-CoV-2 bezobjawowo, inni doświadczaja jedynie symptomów podobnych do przeziębienia, podczas gdy u wielu pacjentów COVID-19 przekształca się w ciężkie, nawet śmiertelne, zapalenie płuc. Pierwsze doniesienia naukowe dotyczace opisu choroby i same-

Słowa kluczowe: ACE2, burza cytokinowa, COVID-19, cukrzyca, makrofagi, monocyty, nikotyna, receptory nikotynowe ACh a4/a7, SARS-CoV-2, zapalenie jąder, zapalenie najądrzy 
go wirusa (sekwencja genomu RNA) (CHAN i współaut. 2020) pochodziły $z$ Chin, gdzie zaczęła się pandemia. Jedną $z$ pierwszych, intrygujacych obserwacji było doniesienie, że palacze w mniejszym stopniu cierpia $z$ powodu COVID-19 niż osoby niepalace (GUAN i współaut. 2020, HUANG i współaut. 2020, LIPPI i HENRY 2020), co szczegółowo opisane będzie poniżej. To właśnie ten pozorny paradoks pozwolił ustalić, że jedna $z$ głównych przyczyn covidowego zapalenia płuc jest tak zwana burza cytokinowa, w której zasadnicza rolę odgrywaja makrofagi, a szczególnie makrofagi płucne.

\section{FUNKCJE MONOCYTÓW \\ I MAKROFAGÓW W UKŁADZIE ODPORNOŚCIOWYM}

Makrofagi to komórki układu odpornościowego należace do białych ciałek krwi, inaczej zwanych leukocytami. Zaangażowane sa one we wrodzona odpowiedź immunologiczną stanowiaca pierwsza linię obrony organizmu przed infekcjami. Ich prekursorami sa monocyty. Makrofagi osiadłe/tkankowe powstaja głównie w czasie życia płodowego $z$ komórek wywodzących się $z$ woreczka żółtkowego, a w ciagu życia odnawiaja się przez proliferację. Jednak, przynajmniej częściowo, ich populacja jest wzbogacana przez różnicowanie się w nie monocytów pochodzacych ze szpiku kostnego i krażacych we krwi zanim zasiedla tkanki organizmu i przekształca się w makrofagi lub komórki dendrytyczne (Gomez Perdiguero i Geissmann 2016). Monocyty, podobnie jak makrofagi, maja silne właściwości żerne, dzięki czemu pochłaniaja wirusy, bakterie, pasożyty, które przedostały się do organizmu, ale również zainfekowane komórki własne oraz ich resztki pozostałe po obumarciu (KLOC i KUBIAK 2021). Poza ta podstawowa funkcją, która wykonuja dzięki procesowi fagocytozy, pełnia druga, równie istotna funkcję jaka jest koordynacja działania układu odpornościowego. Odbywa się to dzięki ich aktywności wydzielniczej, związanej $z$ wytwarzaniem cytokin i czynników wzrostu, działających jako przekaźniki informacji pomiędzy komórkami (GREENE i współaut. 2021). Cytokiny mają zarówno działanie przeciwzapalne jak i prozapalne, i dzięki temu makrofagi i monocyty moga precyzyjnie regulować przebieg procesów zapalnych i indukować lub hamować migracje komórek układu odpornościowego do miejsc zaatakowanych przez infekcje lub urazy. Według dawnego podziału cytokiny wydzielane przez monocyty i makrofagi nosza nazwę monokin, w przeciwieństwie do limfokin wydzielanych przez limfocyty. Ten stary podział nie wytrzymał jednak próby czasu, gdyż okazało sie, że jest nieprecyzyjny i obie grupy leukocytów moga wydzielać zarówno monokiny, jak i limfokiny. Dlatego bardziej wskazany jest podział cytokin w zależności od ich podobieństw strukturalnych i sposobów działania. Podstawowe cytokiny to interferony o działaniu przeciwwirusowym, interleukiny o bardzo szerokim spektrum działania na komórki systemu odpornościowego, chemokiny pobudzające chemotaksję różnych komórek odpornościowych oraz czynniki wzrostu regulujace procesy różnicowania komórek układu odpornościowego. Do tych ostatnich należą np.: czynnik martwicy nowotworów (ang. tumor necrosis factor, TNF), czynnik stymulujacy tworzenie kolonii granulocytów i makrofagów (ang. granulocyte macrophage colony-stimulating factor, GM-CSF) czy czynnik stymulujacy powstawanie kolonii granulocytów (ang. granulocyte colony-stimulating factor, G-CSF) i wiele innych (XU i współaut. 2020, RICCI i współaut. 2021). Cytokiny służą do komunikowania się poszczególnych grup leukocytów $z$ pozostałymi komórkami układu odpornościowego i $z$ innymi tkankami organizmu. Dzięki tym właściwościom monocyty i makrofagi zapewniaja niespecyficzna obronę organizmu przed atakiem wszelkich drobnoustrojów, $z$ którymi organizm nie musiał się zetknąć w przeszłości. A takim właśnie nieznanym dla ludzkiego układu odpornościowego intruzem był na początku pandemii koronawirus SARS$-\mathrm{CoV}-2$

\section{UDZIAE MAKROFAGÓW W PATOFIZJOLOGII COVID-19}

Wspomniana wyżej burza cytokinowa, wywoływana $\mathrm{w}$ płucach pacjentów chorych na ciężka postać COVID-19, jest wynikiem wydzielania nadmiaru cytokin prozapalnych przez makrofagi płucne (MACIOROWSKI i współaut. 2020). Ważnym pytaniem jest więc to, jak $\mathrm{w}$ tej sytuacji dochodzi do zachwiania równowagi wydzielania cytokin przez makrofagi płucne? Otóż bardzo istotna informacja dla zrozumienia tego zjawiska okazało się to, że makrofagi zawierają na swojej powierzchni białko ACE2, które jest receptorem umożliwiajacym wnikanie wirusa SARS-CoV-2 do komórek (BANU i wspólaut. 2020). To zaś oznacza, że koronawirus SARS-CoV-2 może wniknać również do makrofagów po połączeniu się $z$ ich białkiem ACE2 znajdujacym się na ich powierzchni, tak samo jak dzieje się w przypadku wnikania tego wirusa do komórek nabłonka dróg oddechowych czy pęcherzyków płucnych. To właśnie atak SARS-CoV-2 na makrofagi dezorganizuje ich działanie i powoduje wydzielanie nadmiaru cytokin prozapalnych. Co 
gorsza, zakażone makrofagi nie są w stanie zatrzymać tego procesu. $Z$ tego powodu stan zapalny w płucach pogłębia się, a liczba komórek odpornościowych w pęcherzykach płucnych rośnie, gdyż sa one wabione w te miejsca sygnałami wysyłanymi przez makrofagi zakażone koronawirusem. W końcu liczba wszystkich leukocytów w peccherzykach płucnych chorych staje się tak duża, że zatykaja one ich wnętrza, uszkadzaja tkanki oraz gwałtownie upośledzaja i tak ograniczony choroba proces oddychania, przyczyniajacc się do gwałtownego pogorszenia stanu pacjenta i ewentualnie jego śmierci. Bezpośrednia przyczyna ostrego zapaleniu płuc i burzy cytokinowej w COVID-19 jest nie tyle sama infekcja SARS-CoV-2, co niezrównoważona odpowiedź immunologiczna głównie ze strony makrofagów (JAFARZADEH i współaut. 2020) i neutrofilii (patrz STARZYK i współaut. $\mathrm{w}$ tym zeszycie KOSMOSU). Chociaż makrofagi stanowia pierwsza linię obrony naszych organizmów przed infekcjami, to, jak widać $z$ tego opisu, kiedy same zostana zaatakowane przez patogen moga również przyczyniać się do pogłębiania stanów patologicznych lub nawet do śmierci pacjentów. Głównym celem ich działania jest utrzymanie równowagi i koordynacja działania różnych leukocytów, więc kiedy reaguja patologicznie, właśnie ta równowaga zostaje szybko zachwiana (KLOC i KUBIAK 2021). Dlatego jeśli infekcja SARS-CoV-2 zakłóci funkcjonowanie samych makrofagów, to kontrola homeostazy narządów, a szczególnie płuc, zostaje upośledzona, czego skutki moga być bardzo groźne.

\section{EFEKT NIKOTYNY NA MAKROFAGI I NA PRZEBIEG BURZY CYTOKINOWEJ W COVID-19}

Doniesienia $z$ poczatku pandemii $\mathrm{CO}-$ VID-19, które szybko przedostały się do mediów, informowały o tym, że na oddziały intensywnej terapii trafia mniej palaczy tytoniu niż wynikałoby to ze statystyk (MIYARA i współaut. 2020). Była to bardzo zaskakujaca obserwacja, ponieważ palenie tytoniu jest bardzo istotnym czynnikiem podwyższonego ryzyka wszystkich chorób płuc. Palacze powinni więc przechodzić COVID-19 gorzej niż osoby niepalace, bowiem ich płuca sa zwykle w o wiele gorszym stanie niż płuca osób niepalacych, a tak się nie działo (Polosa i CACI 2020). Jedna $z$ przyczyn takiego zaskakujaccego stanu rzeczy może być efekt nikotyny, która łagodzi burzę cytokinowa wywoływana przez zakażone SARS-CoV-2 makrofagi $\mathrm{w}$ ciężkich przypadkach zapalenia płuc powodowanego COVID-19. Nikotyna działa bowiem na makrofagi $\mathrm{w}$ ten sposób, że hamuje wydzielanie przez nie prozapalnych cy- tokin pogłębiajacych stan zapalny płuc. To ogólny opis sytuacji, ale jak to wygląda w szczegółach?

W płucach znajdują się dwa główne typy makrofagów: makrofagi pęcherzykowe, które umiejscawiaja się $\mathrm{w}$ sasiedztwie nabłonka pęcherzyków płucnych, oraz makrofagi śródmiąższowe (prawdopodobnie prekursory makrofagów pęcherzykowych) zlokalizowane głębiej, w miąższu pod nabłonkiem pęcherzyków (Hu i CHRISTMAN 2019). W zdrowych płucach makrofagi pęcherzykowe przejawiaja fenotyp przeciwzapalny, który łagodzi lokalną odpowiedź immunologiczną. Wydzielają one bardzo mało cytokin prozapalnych, co tłumi ewentualny stan zapalny. Jednak podczas zakażenia płuc wywołanego patogennymi bakteriami, grzybami lub wirusami makrofagi pęcherzykowe stanowia pierwsza linię obrony organizmu. Następuje wówczas transformacja ich fenotypu $\mathrm{z}$ przeciwzapalnego na prozapalny $i$ rozpoczynaja szybka synteze i uwalnianie cytokin do przestrzeni międzykomókowych, co powoduje migracje innych komórek układu odpornościowego do płuc. Następnie, w fazie pozapalnej i w fazie gojenia, makrofagi pęcherzykowe powracaja do fenotypu przeciwzapalnego, który sprzyja naprawie uszkodzonych płuc (HUSSELL i Bell 2014, Joshi i współaut. 2018, Hu i CHRISTMAN 2019).

Jak już wspomniano, nasilenie objawów i wysoka śmiertelność u niektórych pacjentów z COVID-19 jest związana $z$ nadreaktywnościa ich układu odpornościowego, spowodowana atakiem wirusa SARS-CoV-2 wywołującego burzę cytokinowa w płucach (YE i współaut. 2020). Analiza histologiczna płuc pacjentów $z$ ciężkim przebiegiem COVID-19 wykazała, że ich pęcherzyki płucne sa wypełnione licznymi makrofagami przy niewielkiej liczbie limfocytów B i T (WANG i współaut. 2020). Wykazano również, że te makrofagi pęcherzykowe wykazuja wysoki poziom ekspresji receptorów ACE2 (enzym konwertujacy angiotensynę 2), które pozwalaja wirusom SARS-CoV-2 wnikać do komórek (VERDECCHIA i współaut. 2020, YAN i współaut. 2020). Badania te wykazały również, że znajdujace się na szczycie wirusowego kolca białko Spike (S), które wiąże się $z$ receptorami ACE2 i ułatwia wniknięcie SARS-CoV-2 do komórek, specyficznie oddziałuje $z$ receptorami ACE2 $\mathrm{w}$ makrofagach płuc, ale nie $\mathrm{z}$ komórkami B i T (WANG i współaut. 2020). Co ważne, wirus SARS-CoV-2 został wykryty wewnatrz makrofagów pęcherzykowych, makrofagów $z$ węzłów chłonnych i ze śledziony oraz $\mathrm{w}$ komórkach nabłonka pęcherzyków płucnych. Wyniki te sugeruja, że u pacjentów $z$ ciężkim przebiegiem COVID-19 to właśnie makrofagi, które są bezpośrednio zaka- 
żone wirusem SARS-CoV-2 moga wzmagać burzę cytokinowa (VERDECCHIA i współaut. 2020, WANG i współaut. 2020, YAN i współaut. 2020;). Wykazano bowiem, że pozytywne efekty terapii przeciwzapalnych, stosowanych w różnych stanach patologicznych, opierają się głównie na hamowaniu zarówno infiltracji makrofagów, jak i produkcji cytokin w tych tkankach (CHEN i współaut. 2017).

Jednak, co bardzo ważne w kontekście działania nikotyny, oprócz receptorów ACE2 makrofagi płucne zawieraja również nikotynowe receptory $\mathrm{ACh}$ a $4 / \mathrm{a} 7$ (nAChR) (ABRIAL i współaut. 2012). Receptory nikotynowe acetylocholiny (cholinergiczne) sa stymulowane przez neuroprzekaźnik acetylocholinę i sa obecne w komórkach układu nerwowego, mięśni i innych narządów (Lu i współaut. 2014). W komórkach odpornościowych, $\mathrm{w}$ tym w makrofagach, receptory nikotynowe $\mathrm{ACh}$ również reguluja działanie układu odpornościowego w stanach zapalnych poprzez sygnalizację za pośrednictwem neuroprzekaźników (DE JONGE i współaut. 2005, ABRIAL i współaut. 2012, LU i współaut. 2014, BÁEZ-PAGÁn i współaut. 2015, CHANGEux i współaut. 2020). Dla wyjaśnienia ich działania w makrofagach szczególnie istotne były badania Lu i współaut. (2014). Wykazały one bowiem, że aktywacja receptorów ACh w makrofagach hamuje wydzielanie prozapalnych cytokin, których normalnym zadaniem jest nasilanie stanu zapalnego. Okazuje się też, że stymulacja makrofagowych receptorów ACh przez acetylocholinę, w sytuacji fizjologicznej uwalniana przez odprowadzajace zakończenia nerwu błędnego lub przez nikotynę u palaczy i użytkowników produktów nikotynowych, hamuje produkcję cytokin prozapalnych i odpowiedź zapalną. Ten nowy szlak regulacyjny nazwano cholinergicznym szlakiem przeciwzapalnym (CAP) (BÁEZ-PAGÁN i współaut. 2015, DE JONGE i współaut. 2005, CHANGEUX i współaut. 2020). W szlaku sygnalizacyjnym CAP, aktywacja makrofagowych receptorów $\mathrm{ACh}$ zapobiega translokacji czynnika NF-kB (pośredniczacego w indukcji cytokin prozapalnych) do jądra komórkowego i ostatecznie aktywuje szlak kinazy tyrozynowej JAK2 i czynnika transkrypcyjnego STAT3 (szlak sygnalizacyjny JAK2-STAT3). To zaś prowadzi do zmniejszenia odpowiedzi zapalnej (DE Jonge i współaut. 2005, BÁEZ-PAGÁN i współaut. 2015, CHANGEUX i współaut. 2020) i ograniczenia lub całkowitego wyeliminowania burzy cytokinowej w płucach. Właśnie to działanie wyjaśniałoby, dlaczego stosowanie nikotyny może zmniejszyć lub wyeliminować burzę cytokinowa u pacjentów $z$ COVID-19 palacych papierosy lub inne produkty zawierajace nikotynę.
Otwiera to również możliwość ewentualnego zastosowania nikotyny lub innych aktywatorów receptorów cholinergicznych jako środków terapeutycznych w walce $z$ COVID-19 i podobnymi infekcjami wywołujacymi zapalenie płuc.

Jednak palenie tytoniu nie powinno być stosowane jako środek leczniczy, gdyż znajdujace się $w$ dymie papierosowym liczne substancje trujace, w tym również sama nikotyna w nieznanych stężeniach, wywołuja wiele chorób i stanowia poważne zagrożenie dla zdrowia i życia. Dlatego ten przypadkowy efekt nikotyny chroniacy w pewnym stopniu przed ciężkim przebiegiem COVID-19 nie może być polecany jako antidotum na tę chorobę. Mniejsza niż statystycznie oczekiwana liczba palaczy tytoniu wśród pacjentów w stanie ciężkim nie oznacza, że wszyscy palacze sa chronieni przez nikotynę zawartą w ich używkach. Jeśli dalsze badania potwier$\mathrm{dza}$, że alkaloid ten rzeczywiście pomaga w przypadku ostrego przebiegu COVID-19, to może on być stosowany w leczeniu. Ale oczywiście musi być podawany w odpowiednim stadium choroby, w precyzyjnie dobranych dawkach i pod kontrola lekarza. Zbyt wczesne podanie nikotyny może wywołać zgubne skutki, gdyż wydzielanie cytokin przez makrofagi jest niezbędnym procesem obronnym organizmu w procesie walki $z$ infekcjac.

Opisany powyżej przykład działania nikotyny pokazuje wyraźnie rolę makrofagów zarówno w procesach obronnych organizmu wywołanych infekcja SARS-CoV-2, jak i w patofizjologii COVID-19. Obserwacja dotyczaca palaczy tytoniu była jednym $z$ pierwszych sygnałów, że makrofagi mogą odgrywać decydująca rolę w poważnym przebiegu COVID-19 połaczonym z burza cytokinowa. Zakażenie makrofagów koronawirusem SARS-CoV-2 powoduje, że działanie tych komórek poczatkowo skierowane na walke $z$ infekcja może stać się groźne dla życia chorego.

\section{ROLA MAKROFAGÓW W ROZNOSZENIU SARS-COV-2 W ORGANIZME CHOREGO NA COVID-19}

Zapewnienie równowagi $\mathrm{w}$ regulacji stanów zapalnych przez makrofagi ma decydujace znaczenie dla prawidłowej homeostazy organizmu. Podejrzewa się, że jedna $z$ przyczyn cukrzycy typu 1 (tzw. cukrzycy insulinozależnej) może być lokalne zapalenie trzustki wywołane przez niezrównoważone działanie zgromadzonych w niej makrofagów. W przypadku COVID-19 makrofagi tkankowe i cyrkulujace w krwiobiegu ich prekursory monocyty, moga odgrywać istotna rolę roznosicieli wirusa SARS-CoV-2 w organizmie (KLOC i współaut. 2020) 
W wyspach trzustkowych występuje pięć typów komórek: komórki beta wydzielające insulinę, komórki alfa wydzielające glukagon, komórki delta wydzielajace somatostatynę, komórki epsilon wydzielajace grelinę (tzw. „hormon głodu”, który stymuluje przyjmowanie pokarmu, odkładanie tłuszczu i uwalnianie hormonu wzrostu) oraz komórki wydzielające polipeptyd trzustkowy (PP) regulujace gospodarke hormonalna i funkcje wydzielnicze trzustki. Ponadto wyspy trzustkowe zawieraja populacje zlokalizowanych w niej makrofagów. Makrofagi wysp trzustkowych sa samoodnawialne i rzadko, jeśli w ogóle, są uzupełniane przez monocyty pochodzace ze szpiku kostnego i krwi (CARRERo i współaut. 2017). Cukrzyca wywoływana jest utrata funkcjonalnych komórek $\beta \mathrm{w}$ trzustce. Badania przedkliniczne i kliniczne wskazuja, że zwiększona liczba komórek zaangażowanych w odporność wrodzona, jak właśnie makrofagi i wytwarzane przez nie czynniki prozapalne maja wpływ na zanikanie komórek $\beta \mathrm{w}$ cukrzycy na drodze apoptozy (BÖNI-SCHNETZLER i MEIER 2019). Ale obserwuje się również oddziaływanie stanu cukrzycowego na metabolizm monocytów i makrofagów głównie poprzez wysoki poziom glukozy w organizmie. Ten wpływ cukrzycy skutkuje zakłóceniem procesów odporności wrodzonej i stanami zapalnymi (ESPER i współaut. 2008, CASQueIro i współaut. 2012, Ayala i współaut. 2019). Prawidłowo działające makrofagi chronia trzustkę zapewniajac jej homeostazę. Ale w niektórych przypadkach moga także nasilać przebieg cukrzycy poprzez zwiększenie stanów zapalnych wysp trzustkowych i wplyw na proliferacje komórek $\beta$ (YING i współaut. 2019). Badania na modelu mysim cukrzycy typu pierwszego wykazały, że choroba ta sprzyja zapalnemu fenotypowi monocytów/makrofagów (KANTER i współaut. 2012)).

Równocześnie cukrzyca jest jedna $z$ chorób zwiększonego ryzyka w COVID-19. Większe prawdopodobieństwo wystapienia ciężkiego przebiegu COVID-19 u cukrzyków jest zwiazzane w dużym stopniu ze zwiększona ekspresja enzymu konwertujaccego angiotensynę 2 ACE2 - receptora dla wnikania koronawirusów do komórek ludzkich (RocA-Ho i współaut. 2017, ERENER 2020, YANG i współaut. 2020). W dodatku leki, którymi leczeni sa chorzy na cukrzycę, m.in. agoniści glukagonopodobnego peptydu I (GLP-1) lub leki na nadciśnienie i statyny, jeszcze bardziej zwiększają ekspresję ACE2 (DRUCKER 2020). Tak więc pacjenci $z$ cukrzyca staja się nie tylko głównym celem infekcji SARS-CoV-2, ale mogą również rozwinąć wyższy poziom wiremii $z$ powodu nadekspresji receptorów wirusa ACE2 w wielu typach komórek, co sprzyja replikacji SARS-CoV-2.

Istnieje też podejrzenie, że COVID-19 może wywoływać cukrzycę u szczególnie podatnych na nią pacjentów (CARUSO i współaut. 2020, RUBino i współaut. 2020). Zdaja się to potwierdzać opisy przypadków pojawiania się cukrzycy po przebyciu COVID-19 u tych osób (MARCHAND i współaut. 2020). Taka hipotezę wysunięto również po epidemii SARS z 2002 r. (YANG i współaut. 2010).

Jak już wspominałem powyżej, SARS-CoV-2 infekuje wiele typów komórek posiadających na powierzchni receptory ACE2, w tym makrofagi i komórki $\beta \mathrm{w}$ trzustce. Istnieje kilka prawdopodobnych mechanizmów odpowiedzialnych za wywołanie cukrzycy w COVID-19 (KLOC i współaut. 2020). Jedną $z$ możliwości jest to, że podobnie jak w przypadku SARS-CoV-2 w płucach, infekcja makrofagów trzustki powoduje burzę cytokinowa $\mathrm{w}$ trzustce. To $\mathrm{z}$ kolei rekrutuje dodatkowe komórki odpornościowe, w tym prozapalne monocyty i makrofagi, wywołujac dodatkowe uszkodzenie wysp trzustkowych i szczególnie wrażliwych komórek $\beta$. Druga możliwość polega na tym, że ponieważ makrofagi i monocyty sa ruchliwe, to po zakażeniu SARS-CoV-2 przenoszą wirusa do wnętrza trzustki wywołujac spustoszenie wśród komórek $\beta$ posiadajacych receptory ACE2 (KLEPPER i BRANCH 2015) Trzecia możliwość jest taka, że infekcja SARS-CoV-2 komórek $\beta$ bezpośrednio je uszkadza, powodujac apoptoze i zmniejszenie ich masy w trzustce. Chociaż ten scenariusz wydawał się najmniej prawdopodobny, ponieważ bezpośrednie uszkodzenie wysp trzustkowych powinno skutkować wyższą niż zgłoszona zapadalność na cukrzycę wywołana przez COVID-19, to jednak pewne dane sugeruja, że infekcja SARS-CoV-2 może rzeczywiście powodować bezpośrednie uszkodzenie komórek $\beta$ produkujacych insulinę (MALLAPATY 2020). Najprawdopodobniej połaczenie tych wszystkich mechanizmów może być odpowiedzialne za rozwój cukrzycy u pacjentów po przejściu COVID-19, szczególnie u tych, którzy jeszcze przed infekcja SARS-CoV-2 mieli zmniejszona liczbe komórek $\beta \mathrm{w}$ trzustce.

U większości zakażonych dzieci COVID-19 powoduje głównie łagodne objawy, ale może jednak powodować wiele stanów zapalnych i powikłań, w tym wieloukładowy zespół zapalny u dzieci (MIS-C). Obserwuje się również potencjalny zwiazek zapalenia najądrzy lub jąder u chłopców równocześnie z COVID-19, co sugeruje, że zapalenie to może być wywołane bezpośrednio działaniem SARS-CoV-2 (GAGLIARDI i współaut. 2020, WRONOWSKI i współaut. 2021). Wysoki poziom receptorów ACE2 stwierdzono bowiem w spermatogo- 
niach oraz $\mathrm{w}$ komórkach Leydiga i $\mathrm{w}$ komórkach Sertoliego jader. Obecność ACE2 pozwala wirusowi infekować te komórki i tym samym uszkadzać zaatakowane narzady nawet $\mathrm{w}$ przypadkach bezobjawowego przebiegu COVID-19. U osób $z$ objawami oddechowymi, RNA wirusa SARS-CoV-2 jest wykrywalny w nasieniu podczas ostrej fazy COVID-19, a nawet później (LI i współaut. 2020). Te dane sugeruja możliwość realnego związku infekcji SARS-CoV-2, nawet bezobjawowej, $z$ zapaleniem jąder i najądrzy. Również $\mathrm{w}$ tym przypadku zainfekowane SARS-CoV-2 mobilne monocyty i makrofagi moga być wektorem przenoszacym wirusa $z$ dróg oddechowych $w$ okolice jąder. Doniesienia dotyczace współistniejacego COVID-19 i zapalenia jader lub najadrzy dotycza jak dotąd wyłącznie chłopców, a nie dorosłych mężczyzn. Wydaje się zatem, że zapalenie tych narząóow związane $\mathrm{z}$ zakażeniem SARS-CoV-2 może być specyficzne dla dzieci. Co więcej, u dzieci COVID-19 daje lagodne lub w ogóle nie daje objawów i tylko pacjenci $z$ najcięższymi przypadkami zapalenia jąder trafiaja do szpitala, gdzie wykonuje sie rutynowe testy PCR na obecność SARS-CoV-2. Dlatego moga być wykrywalne bardzo rzadko i szczególnie u tych dzieci, które moga być bardziej wrażliwe na ból w tych okolicach ciała.

\section{PODSUMOWANIE}

SARS-CoV-2 okazał się wirusem, który potrafi zdezorganizować funkcjonowanie makrofagów i monocytów. I to do tego stopnia, że staja się one większym zagrożeniem dla życia pacjenta chorego na COVID-19 niż sama infekcja wirusowa. Dość przypadkowa obserwacja, że wśród pacjentów chorych na COVID-19 znajduje się mniej palaczy tytoniu niż można było przewidzieć, naprowadziła na trop wskazujący na centralną rolę makrofagów w wywoływaniu burzy cytokinowej w płucach ciężko chorych pacjentów. Podobnie korelacje między COVID-19 i pojawianiem się cukrzycy lub zapalenia jąder czy najadrzy sugeruja, że w dużym stopniu odpowiedzialne moga być za to makrofagi zakażone wirusem SARS-CoV-2. Jesteśmy cały czas w trakcie pandemii COVID-19 i zapewne wiele nowych informacji naukowych, których przybywa $z$ każdym dniem, pozwoli na weryfikacje opisanych tu dotychczasowych ustaleń i hipotez. Niewatpliwie makrofagi i monocyty bèda obiektem jeszcze wielu badań zwiazanych z COVID-19 i infekcja SARS-CoV-2.

\section{Streszczenie}

W tej pracy przeglądowej opisuję, w jaki sposób makrofagi biora udział zarówno w obronie organizmu przed zakażeniem SARS-CoV-2 i COVID-19 i jak moga przyczyniać się do ciężkiego przebiegu tej choroby. Ma- krofagi stanowia pierwsza linię obrony organizmu przed wniknięciem wirusów, w tym koronawirusa SARS-CoV-2. Wywołuja one m.in. stan zapalny pozwalajacy na konsolidację działania całego układu odpornościowego w COVID-19. Makrofagi sa jednak również zakażane koronawirusem, a wówczas wydzielaja zbyt dużo cytokin i traca zdolność do wygaszania stanu zapalnego. Nikotyna, działając na receptory nikotynowe ACh a4/a7 (nAChR) może łagodzić prozapalne działanie zakażonych SARS-CoV-2 makrofagów i zmniejszać wywołana przez nie burzę cytokinowa w płucach. Monocyty, które sa komórkami prekursorowymi makrofagów, i makrofagi tkankowe moga przenosić SARS-CoV-2 u pacjentów do takich narząóow jak: jądra, najądrza czy trzustka i wywoływać w nich proces zapalny, który w przypadku trzustki może powodować cukrzyce.

\section{LITERATURA}

Abrial C., Delyle S. G, Buenestado A., Naline E., PAPKE R., DEvillier P., 2012. Role of nicotinic receptors in the regulation of cytokines production by human lung macrophages. Eur. Respirat. J. 40 (Suppl. 2), 4540.

ayala T. S., Tessaro F. H. G., Jannuzzi G. P., BElla L. M., FERREIRA K. S., MARTINS J. O., 2019. High glucose environments interfere with bone marrow-derived macrophage inflammatory mediator release, the TLR4 pathway and glucose metabolism. Sci. Rep. 9, doi. org/10.1038/s41598-019-47836-8.

BÁEZ-PAGÁN C. A., DELGADO-VÉlEZ M., LASALDE-DOMINICCI J. A., 2015. Activation of the macrophage a7 nicotinic acetylcholine receptor and control of inflammation. J. Neuroimmune Pharmacol. 10, 468-476.

BANU N., PANIKAR S. S., RIERA LEAL L., RIERA LEAL A., 2020. Protective role of ACE2 and its downregulation in SARS-CoV-2 infection leading to Macrophage Activation Syndrome: Therapeutic implications. Life Sci. 256, doi: $10.1016 /$ j.lfs.2020.117905.

BÖNI-SCHNETZLER M., MEIER D. T., 2019. Islet inflammation in type 2 diabetes. Seminars Immunopathol. 41, 501-513.

CARRERO J. A., MCCARTHYA D. P., FERRISA S. T. i współaut., 2017. Resident macrophages of pancreatic islets have a seminal role in the initiation of autoimmune diabetes of NOD mice. Proc. Natl. Acad. Sci. USA 114, E10418-E10427.

Caruso P., LONGO M., Esposito K., MaIORINO M. I., 2020). Type 1 diabetes triggered by covid-19 pandemic: A potential outbreak? Diabetes Res. Clin. Pract. 164, doi: 10.1016/j. diabres.2020.108219

Casoueiro J., Casoueiro J., Alves C., 2012. Infections in patients with diabetes mellitus: a review pathogenesis. Indian J. Endocrinol. Metab. 16, 27-36.

Chan J. F., KoK K. H., Zhu Z., Chu H., To K. K., YUAN S., YUEN K. Y., 2020. Genomic characterization of the 2019 novel human-pathogenic coronavirus isolated from a patient with atypical pneumonia after visiting Wuhan. Emerg. Microbes Infect. 9, 221-236.

ChangeuX J. P., Amoura Z., Rey F., Miyara M. 2020. A nicotinic hypothesis for Covid-19 with preventive and therapeutic implications. C R Biol. 343, 33-39.

Chen C., Yang S., Zhang M., Zhang Z., Zhang S B. i współaut., 2017. Triptolide mitigates radiation-induced pneumonitis via inhibition of al- 
veolar macrophages and related inflammatory molecules. Oncotarget 8, 45133-45142.

Da Costa V. G., Moreli M. L., SAIVISH M. V., 2020. The emergence of SARS, MERS and novel SARS-2 coronaviruses in the 21st century. Arch. Virol. 22, 1-10.

De Jonge W. J., VAN Der Zanden E. P., The F. O., BiJlsma M. F., VAN Westerloo D. J. i współaut., 2005. Stimulation of the vagus nerve attenuates macrophage activation by activating the Jak2-STAT3 signaling pathway. Nat. Immunol. 6, 844-851.

DRUCKER D. J., 2020. Coronavirus infections and type 2 diabetes-shared pathways with therapeutic implications. Endocr. Rev. 41, doi: $10.1210 /$ endrev/bnaa011.

ERENER S., 2020. Diabetes, infection risk and COVID-19. Mol. Metab. 39, doi: 10.1016/j. molmet.2020.101044.

Esper M. A., MOSS M., MARTIN G. S., 2008. The effect of diabetes mellitus on organ dysfunction with sepsis: an epidemiological study. Crit. Care 13, doi: 10.1186/cc7717.

Gagliardi L., BERTACCA C., CENTENARI C. i współaut., 2020. Orchiepididymitis in a boy with COVID-19. Pediatr. Infect. Dis. J. 39, e200-e202.

Gomez Perdiguero E., Geissmann F., 2016. The development and maintenance of resident macrophages. Nat. Immunol. 17, 2-8.

Greene J. T., Brian B. F. 4TH, SEnevirathne S. E., Freedman T. S., 2021. Regulation of myeloid-cell activation. Curr. Opin. Immunol. 73, 34-42.

GuAN W. J., Ni Z. Y., HU Y., LIANG W. H., OU C .Q., HE J. X. i współautl., 2020. Clinical characteristics of coronavirus disease 2019 in China. N. Engl. J. Med. 382, 1708-1720.

Hu G., CHRISTMAN J. W., 2019. Alveolar macrophages in lung inflammation and resolution. Front. Immunol. 10, doi.org/10.3389/fimmu.2019.02275.

Huang C., Wang Y., Li X., Ren L., ZHAO J., Hu Y., 2020. Clinical features of patients infected with 2019 novel coronavirus in Wuhan, China. Lancet 395, 497-506.

Hussell T., BELl T. J., 2014. Alveolar macrophages: plasticity in a tissue-specific context. Nat. Rev. Immunol. 14, 81-93.

JAFARZADEH A., CHAUHAN P., SAHA B., JAFARZADEH S., Nemati M., 2020. Contribution of monocytes and macrophages to the local tissue inflammation and cytokine storm in COVID-19. Lessons from SARS and MERS, and potential therapeutic interventions. Life Sci. 257, doi: $10.1016 / j .1 f s .2020 .118102$.

Joshi N., WALTER J. M., MishaRin A. V., 2018. Alveolar macrophages. Cell Immunol. 330, 86-90.

KANTER J. E., KRAMER F., BARNHART S., AVERILL M. M., VIVEKANANDAN-GIRI A., VICKERY T., LI L. O., BECKER L., YUAN W., CHAIT A. i współaut., 2012. Diabetes promotes an inflammatory macrophage phenotype and atherosclerosis through acyl-CoA synthetase. Proc. Natl. Acad. Sci. USA 109, E715-E724.

KlEPPER A., BRANCH A. D., 2015. Macrophages and the viral dissemination super highway. EC Microbiol. 2, 328-336.

KLOC M., KUBIAK J. Z., 2021. The role of monocytes and macrophages in homeostasis and disease and novel avenues for putative treatments. Int. J. Mol. Sci. 22, doi: 10.3390/ ijms22094927.

Kloc M., Ghobrial R. M., Lewicki S., KubiaK J. Z., 2020. Macrophages in Diabetes Mellitus
(DM) and COVID-19: do they trigger DM? J. Diabetes Metab. Disord. 19, 1-4.

LAI C.-C., SHIH T.-P., KO W.-C., TANG H.-J., HSUEH P.-R., 2020. Severe acute respiratory syndrome coronavirus 2 (SARS-CoV-2) and coronavirus disease-2019 (COVID-19): The epidemic and the challenges. Int. J. Antimicrob. Agents 55, doi: 10.1128/JCM.00512-20.

LI D., JIN M., BAO P. i współaut., 2020. Clinical characteristics and results of semen tests among men with coronavirus disease 2019. JAMA Netw Open 3, doi: 10.1001/jamanetworkopen.2020.8292.

LiPPI G., HENRY B. M., 2020. Active smoking is not associated with severity of coronavirus disease 2019 (COVID-19). Eur. J. Intern. Med. 75, 107-108.

Lu B., Kwan K., Levine Y. A., Olofsson P. S., YANG H., LI J., JOSHI S., WANG H., ANDERSSON U., CHAVAN S. S., TRACEY K. J., 2014. a7 Nicotinic acetylcholine receptor signaling inhibits inflammasome activation by preventing mitochondrial DNA release. Mol. Med. 20, 350358.

Maciorowski D., Mohama S., Alsawi M. A., IlC D. J., GuPTA Y., El IDRISSI S., LODOLCE J. P., KEMPAIAH P., 2020. Molecular insights into severe acute respiratory syndrome coronavirus 2 pathobiology: Dissecting the interplay between cellular innate immunity and immune evasion. Crit. Rev. Immunol. 40, 485-496.

Mallapaty S., 2020. Mounting clues suggest the coronavirus might trigger diabetes. Nature $583,16-17$.

Marchand L., Pecquet M., Luyton C., 2020. Type 1 diabetes onset triggered by COVID-19. Adv. Online Publ., doi: 10.21203/rs.3.rs-38116/v1.

MiYara M., TUBACH F., POURChER V., MORELOT-PANZINI C., PERNET J., HAROCHE J., 2020. Low incidence of daily active tobacco smoking in patients with symptomatic COVID-19. Qeios, doi:10.32388/WPP19W.3.

PolOSA R., CACI G., 2020. COVID-19: counter-intuitive data on smoking prevalence and therapeutic implications for nicotine. Int. Emerg. Med. 15, 853-856.

RicCI D., ETNA M. P., RIzZO F., SANDini S., SEVERA M., COCCIA E. M., 2021. Innate immune response to SARS-CoV-2 infection: from cells to soluble mediators. Int. J. Mol. Sci. 22, doi: $10.3390 /$ ijms22137017.

Roca-Ho H., Riera M., Palau V., Pascual J., SOLER M. J., 2017. Characterization of $A C E$ and ACE2 expression within different organs of the NOD mouse. Int. J. Mol. Sci. 18, doi: $10.3390 /$ ijms 18030563.

Rubino F., Amiel S. A., Zimmet P., Alberti G., BORNSTEIN S., ECKEL R. H., MINGRONE G., Boehm B., Cooper M. E., Chai Z., Del Prato S., Ji L., HOPKINS D., HERMAN W. H., KHUNTI K., MBanya J. C., RenaRD E., 2020. New-Onset Diabetes in Covid-19. N. Engl. J. Med. 383, 789-790.

Verdecchia P., CAVAllini C., Spanevello A., ANGELI F., 2020. The pivotal link between ACE2 deficiency and SARS-CoV-2 infection. Eur. J Int. Med. 76, 14-20.

Wang C., XIE J., ZHAO L., Fei X., Zhang H. i współaut., 2020. Alveolar macrophage activation and cytokine storm in the pathogenesis of severe COVID-19. J. Leukoc. Biol. 108, 17-41.

WRONOWSKI M., WOŻNIAK W., WANKE-RYTT M., JAŻDZEWSKI K., KUCHAR E., KLOC M., KUBIAK J. Z., 2021. Orchiepididymitis in a 14-year-old boy with concurrent SARS-CoV-2 infection. S. 
Afr. J. Child Health 15, doi.org/10.7196/SAJCH.2021.v15i4.1869.

XU Z. S., SHU T., KANG L. i współaut., 2020. Temporal profiling of plasma cytokines, chemokines and growth factors from mild, severe and fatal COVID-19 patients. Signal Transduct Target Ther. 5, doi: 10.1038/s41392020-0211-1.

YAN R., ZHANG Y., LI Y., XIA L., GUO Y., ZHOU Q., 2020. Structural basis for the recognition of SARS-CoV-2 by full-length human ACE2. Science 367, 1444-1448.

YANG J.-K., LIN S.-S., Ji X.-J., GuO L.-M., 2010. Binding of SARS coronavirus to its receptor damages islets and causes acute diabetes. Acta Diabetol. 47, 193-199.
YANG X., YU Y., XU J., ShU H., XIA J., LIU H. i współaut., 2020. Clinical course and 748 outcomes of critically ill patients with SARS-CoV-2 pneumonia in Wuhan, China: a single-centered, retrospective, observational study. Lancet Respir. Med. 8, 475-481.

YE Q., WANG B., MAO J., 2020. Cytokine storm in COVID-19 and treatment. J. Infect. 80, P607-P613.

YING W. LeE Y. S., DONG Y. i współaut., 2019. Expansion of islet- resident macrophages leads to inflammation affecting beta cell proliferation and function in obesity. Cell Metab. 29, 457474.

KOSMOS Vol. 70, 3, 437-444, 2021

\section{JACEK Z. KUBIAK ${ }^{1,2}$}

${ }^{1}$ Department of Experimental Embryology, Institute of Genetics and Animal Biotechnology PAS, Postępu 36A, Jastrzębiec, 05-552 Magdalenka, ${ }^{2}$ UnivRennes, UMR 6290, CNRS, Institute of Genetics and Development of Rennes, Faculty of Medicine, Rennes, France, E-mail: j.kubiak@igbzpan.pl, jacek.kubiak@univ-rennes1.fr

\section{ROLE OF MACROPHAGES AND MONOCYTES IN SARS-COV-2 INFECTION AND IN SEVERE COVID-19 COURSE}

\section{Summary}

In this review, I describe in an accessible manner how macrophages are involved in both the body's defense against SARS-CoV-2 infection and COVID-19, and how they can contribute to the severe course of this disease. Macrophages constitute the body's first line of defense against the ingress of viruses, including the SARS-CoV-2 coronavirus. Among other actions, they cause inflammation that allows the consolidation of the entire immune system in COVID-19. However, macrophages become also infected with the coronavirus, and in consequence they secrete too much cytokines and lose their ability to extinguish the inflammation. By acting on the ACh a4/a7 nicotinic receptors (nAChR), nicotine may attenuate the pro-inflammatory effects of SARS-CoV-2 infected macrophages and reduce the cytokine storm induced by them in the lungs. Monocytes, which are the precursor cells of macrophages and of at least some tissue macrophages, can carry SARS-CoV-2 in patients to organs such as pancreas, testes and epididymis and induce an inflammatory process that can cause diabetes, orchitis or epididymitis.

Key words: macrophages, monocytes, COVID-19, SARS-CoV-2, cytokine storm, ACE2, ACh a4/a7 nicotinic receptors, nicotine, diabetes, orchitis, epididymitis 